\title{
Effect of Tillage Practices on Vertical Distribution of Phytophthora sojae
}

\author{
F. Workneh, X. B. Yang, and G. L. Tylka, Department of Plant Pathology, Iowa State University, Ames 50011
}

\begin{abstract}
Workneh, F., Yang, X. B., and Tylka, G. L. 1998. Effect of tillage practices on vertical distribution of Phytophthora sojae. Plant Dis. 82:1258-1263.

The vertical distribution of Phytophthora sojae was investigated in soil samples collected in the spring of 1994 from soybean fields at 62 locations in Illinois, Indiana, Iowa, and Minnesota. In the fall of 1995, soil samples were collected from 18 additional locations in Illinois and Iowa. Each location consisted of a pair of no-till and conventional-till fields, and soil samples were collected from arbitrarily selected locations in each field at $0-$ to $7.5-\mathrm{cm}$ and $7.5-$ to $15-\mathrm{cm}$ depths. Separate intensive sampling was made in the spring of 1995 from two pairs of adjacent no-till and conventional-till fields at the Iowa State University Northeast Research Farm, in which samples were collected from 0- to 30-cm depth in increments of $5 \mathrm{~cm}$. Samples were assayed for $P$. sojae with the use of a leaf-disk bioassay. In the 1994 regional samples, there was greater recovery of $P$. sojae $(P \leq 0.05)$ at 0 - to $7.5-\mathrm{cm}$ depth in the no-till samples than in the conventional-till samples for all states except Minnesota. The fall 1995 samples from Illinois followed a similar trend $(P=0.05)$; whereas samples from Iowa showed no significant difference between tillage systems. At depths greater than $7.5 \mathrm{~cm}$, there was generally no difference in detection frequency of $P$. sojae between tillage systems. Samples from the Northeast Research Farm followed patterns of vertical distribution similar to those of the regional samples. In no-till fields, the detection frequency of $P$. sojae was greatest near the soil surface; two to three times greater than that of the conventional-till fields at this depth. In the conventional-till fields, however, the frequency of recovery peaked at $20 \mathrm{~cm}$ and was comparable at these depths to those of no-till fields. There was a positive correlation between the percentage of leaf disks colonized and residue dry weights in the no-till fields $(r=0.84, P=0.04$; and $r=0.86, P=0.03)$ but not in the conventional-till fields $(r=-0.06, P=0.90$; and $r=-0.60, P=0.17)$. The recovery of $P$. sojae in greater frequency near the soil surface in no-till fields than in conventional-till fields suggests that the potential for damping-off may be greater in no-till fields than in conventional-till fields.
\end{abstract}

Additional keywords: conservation tillage, minimum-till, reduced-till, surface residue, Phytophthora root and stem rot

Phytophthora root and stem rot of soybean, caused by Phytophthora sojae, is a major disease of soybean worldwide (23). In the United States, the disease is widely distributed in most soybean-producing regions and is estimated to cause an annual yield loss of up to half a million metric tons (34). Reduction in yield may result from stand losses that arise from pre- and postemergence damping-off or from wilting or stunting of infected older plants. Even though infection can occur at any stage during plant development (24), most of the damage is believed to result from infection at the seedling stage.

As with other diseases caused by Phytophthora species (8), environmental con-

Corresponding author: F. Workneh

E-mail: fekede@iastate.edu

Journal Series J-17712 of the Iowa Agriculture and Home Economics Experiment Station Project 2869.

Accepted for publication 6 August 1998.

Publication no. D-1998-0910-01R

(C) 1998 The American Phytopathological Society ditions, such as soil compaction, that prolong the saturation of the soil favor development of the disease (10). There is little information on the effect of tillage practices on Phytophthora root and stem rot of soybean. Tachibana (30) observed more severe root rot in conservation tillage (ridge-till) treatments than in conventional tillage treatments. Schmitthenner and Van Doran (25) and Dick and Van Doran (7) reported greater yield reduction of a susceptible cultivar in Phytophthora-infested no-till plots than in conventional-till plots, and they assumed this effect was caused by the disease.

Tillage has been a major component of agricultural practices, with the primary objectives of weed control and seed bed preparation. Generally, conventional tillage practices encompass burial of surface residues and loosening of crusted surfaces and dense soil layers. However, in the last few years, there has been increased emphasis on maintenance of surface crop residues, primarily to prevent wind and water erosion (2). Consequently, there is a shift from the traditional clean-till seed bed preparation to adoption of conservation tillage practices that maintain greater than $30 \%$ residue cover after planting. Such tillage practices involve little (reduced-till) or no (no-till) soil disturbances between harvest and planting. Within the last decade, no-till acreage in the north central United States has increased from 5.4 to $29.6 \%$ of the total soybean production area (2).

The role of crop residues in survival of plant pathogens has long been understood $(5,6,16,28)$. For many plant pathogens, crop residues provide shelter and a food base for reproduction. Crop residues left on the soil surface decompose more slowly than buried residues (9), which may lead to concentration of inhabiting pathogens near the soil surface (20). P. sojae is a homothallic fungus and, therefore, produces abundant oospores in infected root and stem tissues $(24,26)$. Even though oospores may survive in soil (32), infested soybean root and stem residues are believed to be the primary sources of inoculum (24). Therefore, the vertical distribution of the pathogen may be directly related to the vertical distribution of soybean residues, and this in turn may have significant impact on seedling disease caused by the pathogen. The impact may be difficult to demonstrate in the field because of the uncertainty of favorable environmental conditions and the existence of many races of the fungus $(1,35)$. However, one would expect that high population densities of the pathogen near the soil surface may lead to greater risk of damping-off than similar densities in the soil profile. Schmitthenner and Van Doran (25) discussed the possible occurrence of such scenarios and emphasized the need for further investigation. Currently, information is lacking on how the vertical distribution of the pathogen is affected by tillage practices. Such information would be useful in assessing risks associated with particular tillage practices, especially pertaining to Phytophthora root and stem rot of soybean. In addition, this information may be beneficial for making decisions on soil sampling schemes to determine population densities of the pathogen in different management systems. The primary objective of this study was to determine the vertical distribution of propagules of $P$. sojae in no-till and conventional-till fields.

\section{MATERIALS AND METHODS}

In 1994 and 1995, paired soil samples were collected from four states of the north central United States. In addition to these regional samples, separate soil samples were collected in the spring of 1995 from two pairs of no-till and conventional-till 
fields at the Iowa State University Northeast Research and Demonstration Farm at Nashua. The regional samples were collected from two soil depths, and the Nashua samples were collected from six depths.

Regional samples. In June 1994, soil samples were collected from 62 locations (Fig. 1), each with adjacent conventionaltill and no-till soybean fields. Fields were located in Illinois, Indiana, Iowa, and Minnesota and represented 12,10,19, and 10 counties, respectively. Samples were collected again in October 1995 from 10 locations in Illinois and 8 locations in Iowa. The 1995 locations in both states were different from those of 1994.

The 1994 locations were selected in cooperation with either the cooperative extension county agents or the assistance of the farmers. In areas where contacts with either county extension agents or farmers were not possible, fields were identified by the presence or absence of the typically erect remains of cornstalks that characterize no-till fields, coupled with the presence or the absence of signs of tillage operations. All 1995 locations were selected with the help of farmers or county extension agents. At each location, a no-till field was first identified and paired with the nearest conventional-till field of similar size. The no-till and the conventional-till fields at each location were either contiguous or, at most, within $1.6 \mathrm{~km}$ of each other. All soybean fields had been cropped with corn the previous year except one field in Minnesota that was cropped with alfalfa. From each field, 50 arbitrarily located soil cores at depths of 0 to $15 \mathrm{~cm}$ were collected with a 2-cm-diameter soil probe. The soil probe was marked 7.5 and $15 \mathrm{~cm}$ from the tip, and soil cores were separated into shallow $(0$ to $7.5 \mathrm{~cm})$ and deep ( 7.5 to $15 \mathrm{~cm}$ ) components. The samples were transported to the laboratory in sealed boxes on ice and stored at $4^{\circ} \mathrm{C}$ until use. The samples were taken out of cold storage and maintained at 22 to $24^{\circ} \mathrm{C}$ for 15 days prior to bioassay.

Nashua Research Farm samples. Samples were collected from two sites (designated hereafter as sites 1 and 2), each comprising a pair of contiguous no-till and conventional-till fields that had 17 years of the same tillage history. All fields had a prior history of Phytophthora root and stem rot and received similar treatments in all aspects of management except tillage operations. The conventional-till fields were plowed with a moldboard plow every fall after harvest and cultivated every spring before planting. The no-till fields did not receive any tillage operations except the opening of seed furrows with the planter once every spring. The fields at each site had been rotated to corn and soybean for as long as their tillage history. The year prior to sample collection, the fields at site 1 were cropped with soybean, while the fields at site 2 were cropped with corn. The fields at site 1 were nearly flat; whereas the fields at site 2 were located on a gentle slope of 0 to $2 \%$. Each field was slightly less than 0.5 ha.

Soil samples were collected with a 2$\mathrm{cm}$-diameter soil probe from fields at both sites in the third week of April 1995. From each field, samples were collected to a depth of $30 \mathrm{~cm}$ in increments of $5 \mathrm{~cm}$. Samples were collected in an $\mathrm{X}$ pattern, and cores (50 soil cores per increment) from the same depth were bulked. The samples were handled and maintained until use as described above.

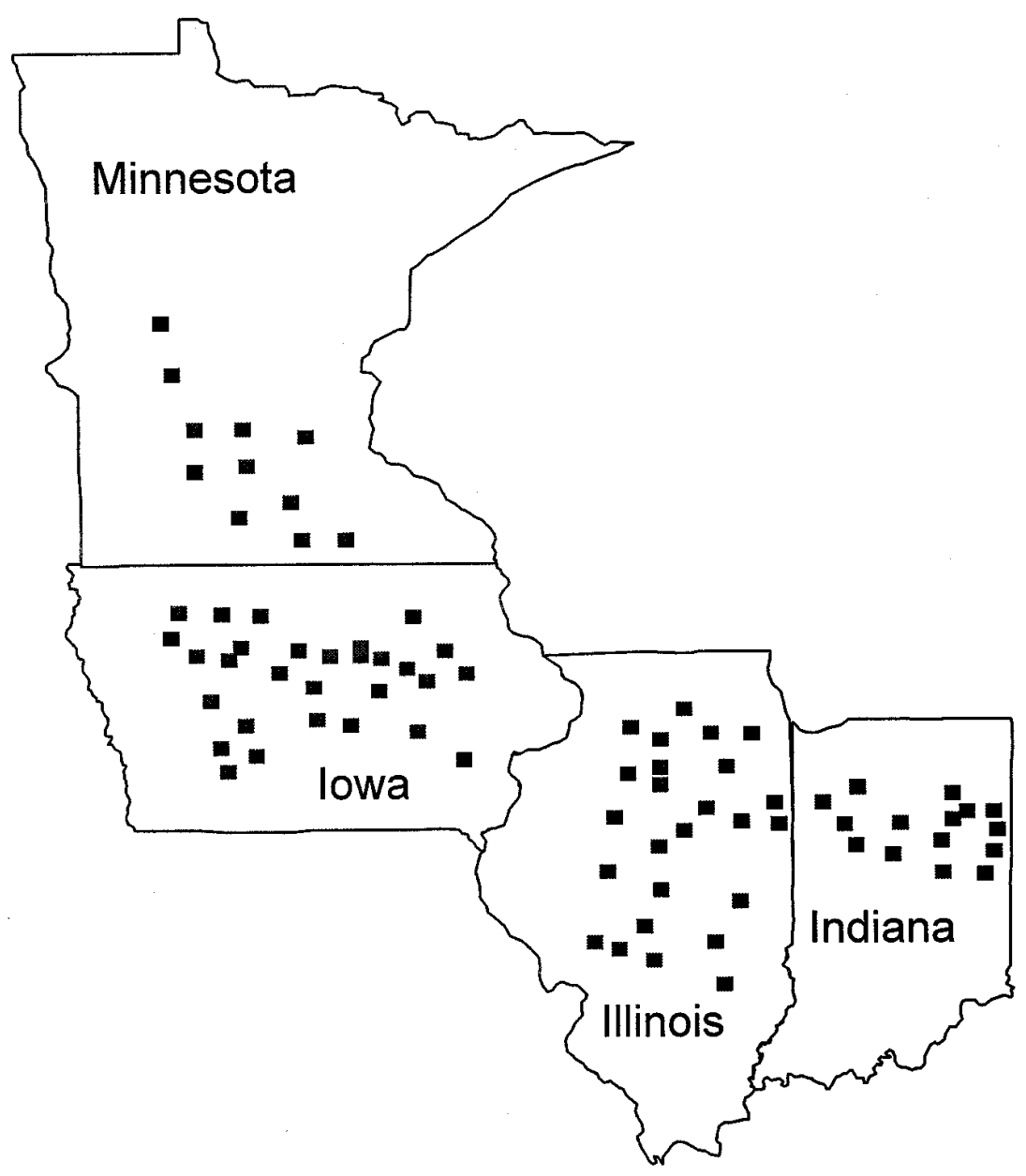

Fig. 1. Locations in four states of the north central region from which soils were sampled from paired no-till and conventional-till fields during spring 1994 and fall 1995.

Table 1. Prevalence of Phytophthora sojae in selected locations of adjacent no-till (NT) and conventional-till (CT) fields sampled in spring 1994 and fall 1995 in four states of the north central region

\begin{tabular}{llcccc}
\hline & & & \multicolumn{2}{c}{ Fields in which $\boldsymbol{P}$. sojae was detected $(\%)^{\mathbf{b}}$} \\
\cline { 5 - 6 } Year & State & Locations (no.) & NT & CT & State total \\
\hline 1994 & Illinois & 15 & 40.0 & 13.3 & 26.7 \\
& Indiana & 16 & 62.5 & 43.8 & 53.1 \\
& Iowa & 20 & 85.0 & 65.0 & 75.0 \\
& Minnesota & 11 & 72.7 & 81.8 & 77.3 \\
1995 & Illinois & 10 & 60.0 & 40.0 & 50.0 \\
& Iowa & 8 & 100.0 & 100.0 & 100.0 \\
\hline
\end{tabular}

${ }^{a}$ Each location consisted of a no-till (NT) and a conventional-till (CT) field.

${ }^{\mathrm{b}}$ The values are means of the corresponding locations. A field was considered positive if $P$. sojae was detected in samples from either of the two depths $(0$ to $7.5 \mathrm{~cm}$ and 7.5 to $15 \mathrm{~cm})$ or both. 
and $22.5 \%$ sand, silt, and clay, respectively) contained in $475-\mathrm{ml}$ perforated plastic cups. The soil columns were watered to saturation and left to drain for 96 h. The samples then were flooded with distilled-deionized water, and ten $0.8-\mathrm{cm}$ diameter soybean leaf disks were floated on the surface of the water pooled above the soil surface. The leaf disks were obtained from young but fully unrolled leaves of the cultivar Sloan (susceptible to all known races). After $24 \mathrm{~h}$, the leaf disks were removed and surface-sterilized with $0.05 \% \mathrm{NaOCl}$ for $30 \mathrm{~s}$, then plated onto a selective medium (5 disks per 9-cm-diameter plate) containing hymexazol at 40 $\mathrm{mg} / \mathrm{liter}(14)$. The plates were incubated in dark at 22 to $24^{\circ} \mathrm{C}$. The percentage of leaf disks colonized by $P$. sojae was determined after 4 days. Typical cultures of the isolates that were obtained in this process were shown to be pathogenic to susceptible soybean cultivars (35).

Bioassay of Nashua samples. Population densities of $P$. sojae in the Nashua samples were assessed as described above except that four subsamples and 20 leaf disks per subsample were used in the bio-

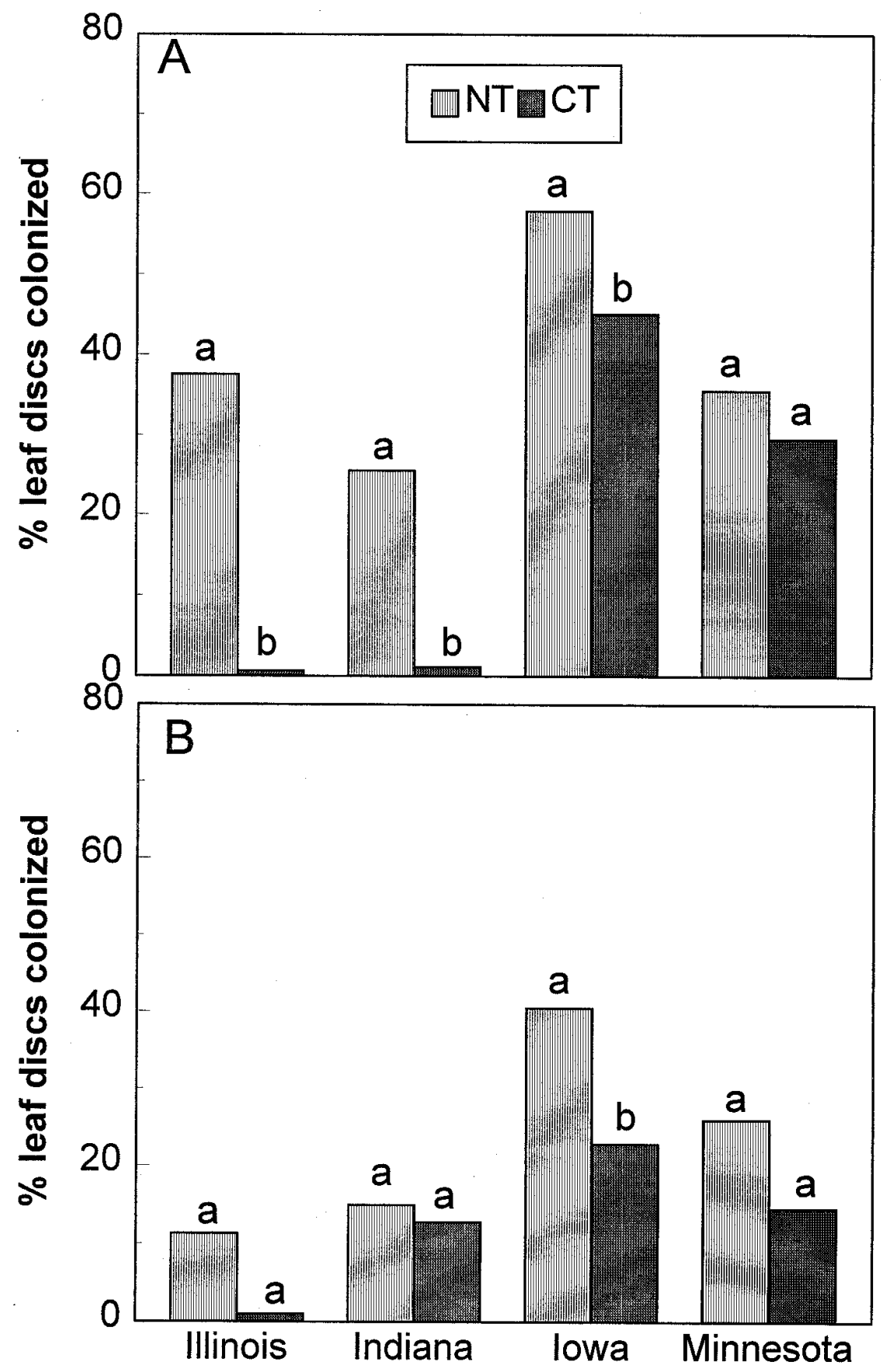

Fig. 2. Recovery of Phytophthora sojae (as determined by a leaf-disk bioassay) in no-till and conventional-till fields at depths of 0 to $7.5 \mathrm{~cm}(\mathbf{A})$ and 7.5 to $15 \mathrm{~cm}(\mathbf{B})$ in samples collected from Illinois, Indiana, Iowa, and Minnesota in spring 1994. Bars with the same letter within a state are not significantly different according to paired $t$ test $(P \leq 0.05)$. assay. Additionally, part of each soil sample from the Nashua fields was used for measurement of residues. Residues were extracted from $500 \mathrm{~cm}^{3}$ (water displacement method) of each sample with a semiautomatic soil elutriator (4) on $0.6-\mathrm{mm}$ diameter screens. Residues left on the screens were collected, air-dried on greenhouse benches, and weighed.

Data analyses. The incidence of $P$. sojae in each of the two fields at each location was determined from the presence or absence of colonization of the leaf disks by the fungus at any of the two sample depths. The significance of the difference in mean incidence between the tillage systems for individual states then was determined with use of McNemar's test (27), a nonparametric equivalent of the paired $t$ test.

At some of the locations, $P$. sojae was not detected in either of the two fields. Only data from locations in which $P$. sojae was detected in at least one of the two fields were included in the analyses of the recovery of the pathogen. For each location, data from 0 to $7.5 \mathrm{~cm}$ of the no-till field were compared with data from 0 to $7.5 \mathrm{~cm}$ of the conventional-till field. Similarly, data from 7.5 to $15 \mathrm{~cm}$ of the respective tillage systems at each location were compared. To avoid division by zero, 0.01 was added to each value, and the differences in the percentages of leaf disks colonized between the no-till (NT) and the conventional-till (CT) fields for each location at each depth were standardized to the conventional-till value as: $\%$ difference $=$ (NT - CT)/CT. The differences for all locations in each state then were analyzed to determine whether the mean difference was significantly different from zero with the use of $t$ test.

For the Nashua samples, the recovery $P$. sojae at each depth of the no-till fields was paired with that of the conventional-till fields at respective depth and analyzed with the use of $t$ test. The relationship between the recovery of $P$. sojae and residue dry weight at each depth was determined with the use of Pearson's correlation. All statistical analyses were conducted with SAS software (SAS Institute, Cary, NC).

\section{RESULTS}

Regional samples. In the spring 1994 samples, $P$. sojae was detected in $77.4 \%$ of the total locations comprising $58.1 \%$ of the fields sampled across the four states. Fields in Minnesota and Iowa had the greatest prevalence of $P$. sojae (77.3 and $75.0 \%$, respectively), followed by Indiana (53.1\%) and Illinois $(26.7 \%)$ (Table 1). Of the fields in which $P$. sojae was detected, 33.1 and $25 \%$ were no-till and conventional-till fields, respectively. Overall, the prevalence of $P$. sojae was greater in no-till than in conventional-till fields, except in Minnesota. However, McNemar's test showed no significant difference ( $P$ values ranging from 0.16 to 0.56 ) among the matched 
pairs of no-till and conventional-till fields for the individual states (Table 1).

The recovery of $P$. sojae, expressed as the percentage of leaf disks colonized, at 0 to $7.5 \mathrm{~cm}$ depth were greater in no-till samples than in conventional-till samples for all states (Fig. 2A). The paired $t$ test analysis showed that the difference was significant for samples from Illinois, Indiana, and Iowa $(P=0.02, P=0.01, P=$ 0.01 , respectively), but not from Minnesota $(P=0.19)$. Samples from the 7.5 - to $15-\mathrm{cm}$ depth showed a similar trend in recovery, with samples from the no-till fields having greater recovery than those from the conventional-till fields. However, the difference was significant only in samples from Iowa $(P=0.05$; Fig. $2 \mathrm{~B})$.

Samples collected from Illinois and Iowa during the fall of 1995 had greater prevalence of $P$. sojae than those collected in the spring of 1994 (Table 1). The difference in incidence between no-till fields and conventional-till fields was not significant. In samples from Illinois at the $0-$ to $7.5-\mathrm{cm}$ depth, recovery of $P$. sojae was significantly greater in no-till fields than in conventional-till fields $(P=0.05$, Fig. 3A). However, there was no significant difference in $P$. sojae recovery at this depth between the two tillage systems in samples from Iowa. Samples from both states showed no significant difference between the two tillage systems at the $7.5-$ to $15-\mathrm{cm}$ depth (Fig. 3B).

Nashua samples. $P$. sojae was recovered from the upper $10 \mathrm{~cm}$ of the soil from the no-till fields at both sites more frequently than from their respective adjacent conventional-till fields (Figs. 4A and 4B). Recovery of $P$. sojae was greatest near the soil surface in the no-till fields and declined with depth in the first 10 to $15 \mathrm{~cm}$ of the soil. Within this depth range, recovery of the pathogen was two to three times greater in the no-till fields than in the conventional-till fields. Recovery of the pathogen in the conventional-till fields peaked at $20 \mathrm{~cm}$, where it was comparable to that of the no-till fields. Overall, there was greater recovery of $P$. sojae in the notill fields than in the conventional-till fields at both sites $(P=0.05$ and $P=0.06$ for sites 1 and 2, respectively).

In the no-till fields, the vertical distribution of the pathogen followed the vertical distribution of residues (Fig. 5). There was a significant correlation between the percentage of leaf disks colonized and residue dry weight in no-till fields at both sites $(r=$ $0.84, P=0.04$, and $r=0.86, P=0.03$, for sites 1 and 2 , respectively). However, in the conventional-till fields, the relationship was less clear than in the no-till fields $(r=$ $-0.06, P=0.90$, and $r=-0.64, P=0.17$ for sites 1 and 2, respectively).

\section{DISCUSSION}

This study demonstrated that at soil depths close to the surface, there was greater recovery of $P$. sojae in no-till fields than in conventional-till fields. This trend was generally evident in most of the regional samples and in all of the samples from the Nashua Research Farm in Iowa.

The presence of $P$. sojae in greater abundance near the soil surface in no-till fields than in conventional-till fields may be attributed partially to the absence of vertical soil inversion in no-till fields. $P$. sojae is primarily a root-infecting, soilborne pathogen. However, lesions from root infection can extend on the stem up to the tenth node (23), and abundant oospores are produced in infected stems (24). In notill fields, such stems remain on or near the soil surface after harvest as part of the residue. When the infested stem residues decompose, oospores may be released to the immediate vicinity (near the soil sur-
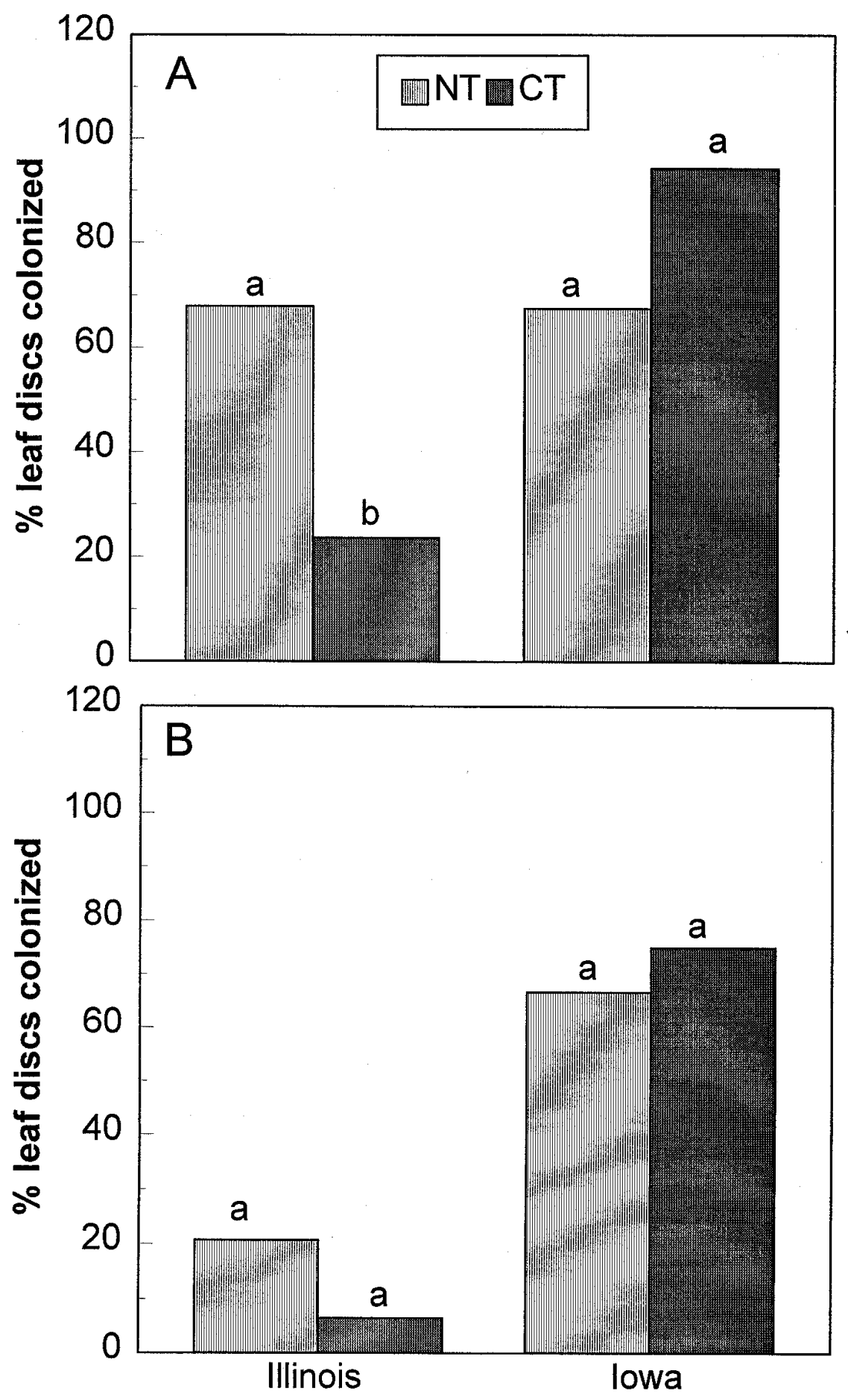

Fig. 3. Recovery of Phytophthora sojae (as determined by a leaf-disk bioassay) in no-till and conventional-till fields at depths of 0 to $7.5 \mathrm{~cm}(\mathbf{A})$ and 7.5 to $15 \mathrm{~cm}(\mathbf{B})$ in samples collected from Illinois and Iowa in fall 1995. Bars with the same letter within a state are not significantly different according to paired $t$ test $(P \leq 0.05)$. 


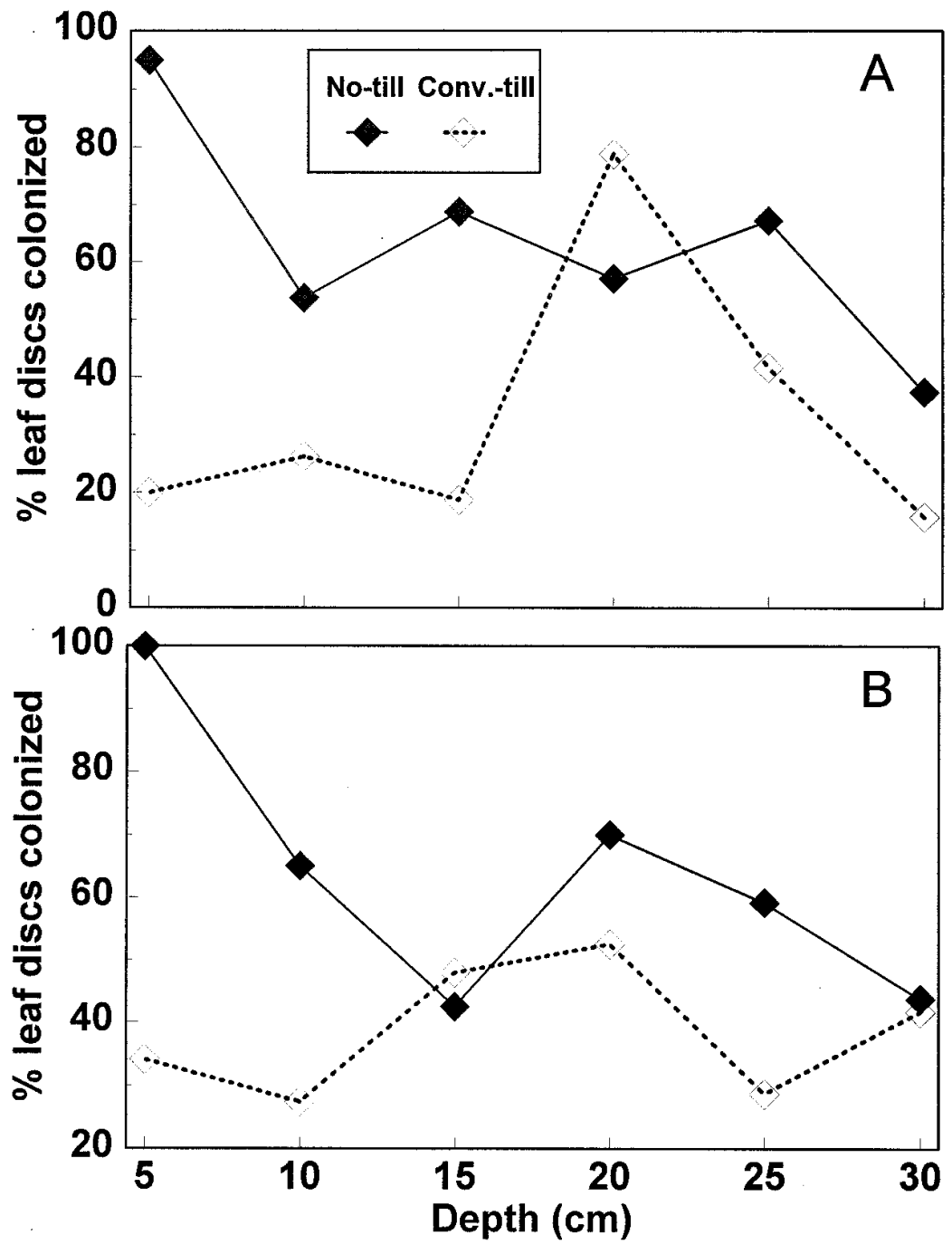

Fig. 4. Relationships between soil depth and recovery of Phytophthora sojae in no-till (continuous lines) and conventional-till fields (dotted lines ) at sites 1 (A) and 2 (B) at the Nashua Research Farm. Data point from each depth of no-till fields is paired with that of conventional-till fields to test the difference between the tillage systems; no-till fields had greater recovery of Phytophthora sojae than conventional-till fields according to $t$ test $(P=0.05$ and $P=0.06$ for sites 1 and 2 , respectively).

face), where they may remain in aggregates for a long period. In addition, remains of infested, standing stubble and primary roots near the soil surface persist for a long period, more or less intact, unlike those in the conventional-till fields, which are subjected to the shear and tear of plowing and cultivation. In no-till fields, when the stubble and the primary roots near the surface decompose, they may serve as additional sources of propagules that may be deposited near the soil surface. Tillage operations fragment, bury, and distribute crop residues along with the inhabiting pathogens throughout the depth of operation. During such operations, significant proportions of propagules may be displaced downward from regions near the soil surface. This displacement of propagules may account for the existence of $P$. sojae in greater abundance further down from the soil surface than near the surface in conventional-till fields.
The survival of plant pathogens in crop residues has been well-documented (27), and for many plant pathogens, surface crop residues, especially in no-till fields, have been associated with increase in diseases $(13,16,21,22,29)$. In samples from the notill fields at the Nashua research farm, the percentage of leaf disks colonized by $P$. sojae significantly correlated with residue dry weight. However, in the conventionaltill fields, the relationship between residue dry weight and recovery of $P$. sojae was not as clear. The lack of a clear relationship may be attributed to the fact that buried residues decompose faster than surface residues (9), and the survival ability of $P$. sojae in fragmented and decomposing soybean tissues in the soil may have been reduced.

Generally, soybean seeds are planted within the top 5 to $6 \mathrm{~cm}$ of the soil. The relative abundance of propagules of $P$. sojae in no-till fields may have important implications for damping-off of soybean. In no-till fields, germinating seeds may be exposed to greater risk of pre- and postemergence damping-off than in the conventional-till fields in which $P$. sojae densities were lower in the seed placement zone. Meyer and Sinclair (15), in working with the same pathogen and host, showed that stem lesions develop when the inoculum is placed at 1 or $4 \mathrm{~cm}$ below the soil surface, but not at $9 \mathrm{~cm}$. They further demonstrated that root and shoot dry weights of soybean increase with increase in depth of inoculum placement.

No-till fields maintain more surface residues and are more compact than conventional-till fields, at least early in the season (12). Consequently, no-till fields retain more moisture $(3,19)$ than conventional-till fields, a condition that favors development of damping-off (24). Compaction (17), long saturation periods, and high propagule densities of $P$. sojae may increase the risks of damping-off in no-till fields.

The leaf-disk bioassay is a semiquantitative technique, and there are advantages and disadvantages to its use in estimating propagule densities in the soil $(11,31)$. In this method, the production of sporangia and zoospores is enhanced through a wetting and drying cycle. The enhancement of spore production may lead to colonization of all or most of the leaf disks if there are initially high population densities of the fungus in the soil. Consequently, the method may fail to detect differences between treatments. However, this technique has been successfully used in the past for other Phytophthora spp. when the fungus was at low population densities $(18,33)$. In fact, the percentage of leaf disks colonized was shown to be correlated with disease severity in the field better than the conventional dilution plating method (18). In our study, we had a high frequency of recovery of $P$. sojae only in samples collected from Iowa during the fall of 1995 (nearly 100\% of the leaf disks were colonized in approximately $50 \%$ of the samples), and that may have resulted in the lack of difference observed between the tillage systems.

In the regional samples, the history of the individual fields, such as the number of years under a particular tillage management regime, might have helped refine our results, but such information was not available. However, by pairing no-till and conventional-till fields at each location, consistent results across the states were obtained. The level of inoculum in the soil is only one aspect of the disease triangle, especially for diseases caused by Phytophthora species, in which environmental factors play a major part. In this investigation, $P$. sojae was recovered in greater frequency near the soil surface in no-till fields than in conventional-till fields. In light of this result, we believe that the potential for disease caused by $P$. sojae in no- 


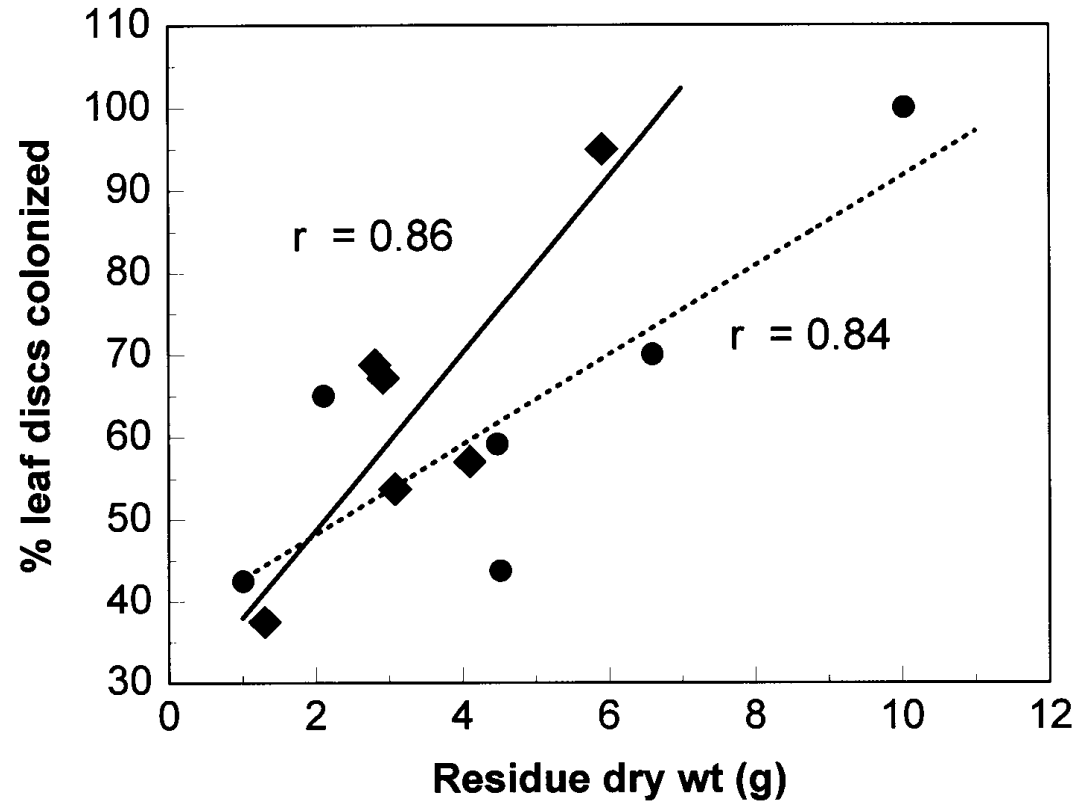

Fig. 5. Relationships between recovery of Phytophthora sojae and residue dry weights in no-till fields at sites 1 (diamonds) and 2 (circles) at the Nashua Research Farm.

till fields is greater than in conventional-till fields.

\section{ACKNOWLEDGMENTS}

This project was supported by the Iowa Soybean Promotion Board, the Northcentral Soybean Research Program, and Hatch Act and State of Iowa Funds. We thank T. S. Abney for valuable information on soybean production for Indiana. We also thank J. J. Nelson, K. Elbasher, and H. A. Roozen for technical assistance. P. Lundeen and A. Bower helped locate fields in Iowa and Illinois.

\section{LITERATURE CITED}

1. Abney, T. S., Melgar, J. C., Richards, T. L., Scott, D. H., Grogan, J., and Young, J. 1997. New races of Phytophthora sojae with Rps1-d virulence. Plant Dis. 81:653-655.

2. Anonymous. 1997. Crop residue management: Midwest Region. Conservation Technology Information Center, West Lafayette, IN.

3. Belvins, R. L., Cook, D., Phillips, S. H., and Phillips, R. E. 1971. Influence of no-tillage on soil moisture. Agron. J. 63:593-596.

4. Byrd, D. W., Barker, K. R., Jr., Ferris, H., Nusbaum, C. J., Griffen, W. E., Small, H. R., and Stone, C. A. 1976. Two semi-automatic elutriators for extracting nematodes and certain fungi from soil. J. Nematol. 8:206-212.

5. Cook, J. R., and Haglund, W. A. 1991. Wheat yield depression associated with conservation tillage caused by root rot pathogens not phytotoxins from the straw. Soil Biol. Biochem. 23:1125-1132

6. de Nazareno, N. R. X., Lipps, P. E., and Madden, L. V. 1993. Effect of levels of corn residue on the epidemiology of gray leaf spot of corn in Ohio. Plant Dis. 77:67-70.

7. Dick, W. A., and Van Doran, D. M. 1985. Continuous tillage and rotation combinations effects on corn, soybean, and oat yields. Agron. J. 77:459-465.

8. Duniway, J. M. 1983. Role of physical factors in development of Phytophthora diseases. Pages 175-187 in: Phytophthora: Its Biology,
Taxonomy, Ecology, and Pathology. D. C. Erwin, S. Bartincki-Garcia, and P. H. Tsao, eds. American Phytopathological Society, St. Paul, MN.

9. Ghidey, F., and Alberts, E. E. 1993. Residue type and placement effects on decomposition: Field study and model evaluation. Trans. ASAE 36:1611-1617.

10. Gray, L. E., and Pope, R. A. 1986. Influence of soil compaction on soybean stand, yield, and Phytophthora root rot incidence. Agron. J. 78:189-191.

11. Larkin, R. P., Ristaino, J. B., and Campbell, C. L. 1995. Detection and quantification of Phytophthora capsici in soil. Phytopathology 85:1057-1063.

12. Lindstrom, M. A., and Onstad, C. A. 1984. Influence of tillage systems on soil physical parameters and infiltration after planting. J. Soil Water Conserv. 39:149-152.

13. Lipps, P. E. 1988. Spread of corn anthracnose from surface residues in continuous corn and corn-soybean rotation plots. Phytopathology 78:756-761.

14. Massago, H., Yoshikawa, M., Fukuda, M., and Nakanishi, M. 1977. Selective inhibition of Pythium spp. on a medium for direct isolation of Phytophthora spp. from soils and plants. Phytopathology 67:425-428.

15. Meyer, W. A., and Sinclair, J. B. 1972. Root reduction and stem lesion development on soybeans by Phytophthora megasperma var. sojae. Phytopathology 62:1414-1416.

16. Moore, K. J., and Cook, R. J. 1984. Increased take-all of wheat with direct drilling in the Pacific Northwest. Phytopathology 74:10441049.

17. Moots, C. K., Nickell, C. D., and Gray, L. E. 1988. Effects of soil compaction on the incidence of Phytophthora megasperma f. sp. glycinea in soybean. Plant Dis. 72:896-900.

18. Neher, D. A., McKeen, C. D., and Duniway, J. M. 1993. Relationships among Phytophthora root rot development, $P$. parasitica populations in soil, and yield of tomatoes under commercial field conditions. Plant Dis.
77:1106-1111.

19. Power, J. F., Wilhelm, W. W., and Doran, J. W. 1986. Crop residue effects on soil environment and dryland maize and soybean production. Soil Till. Res. 8:101-111.

20. Rothrock, C. S. 1992. Tillage systems and plant disease. Soil Sci. 154:309-315.

21. Rothrock, C. S., Hobbs, T. W., and Phillips, D. V. 1985. Effects of tillage and cropping system on incidence and severity of southern stem canker of soybean. Phytopathology 75:1156-1159.

22. Rovira, A. D. 1986. Influence of crop rotation and tillage on Rhizoctonia bare patch of wheat. Phytopathology 76:669-673.

23. Schmitthenner, A. F. 1985. Problems and progress in control of Phytophthora root rot of soybean. Plant Dis. 69:362-368.

24. Schmitthenner, A. F. 1989. Phytophthora root rot. Pages 35-38 in: Compendium of Soybean Diseases, 3rd ed. J. B. Sinclair and P. A. Backman, eds. American Phytopathological Society, St. Paul, MN.

25. Schmitthenner, A. F., and Van Doran, D. M 1985. Integrated control of root rot of soybean caused by Phytophthora megasperma f sp. glycinea. Pages 263-266 in: Ecology and Management of Soilborne Plant Pathogens. C. A. Parker, A. D. Rovira, K. J. Moore, P. T. W. Wong, and J. F. Kollmorgen, eds. American Phytopathological Society, St. Paul, MN.

26. Slusher, L. R., and Sinclair, J. B. 1973. Development of Phytophthora megasperma var. sojae in soybean roots. Phytopathology 63:1168-1171.

27. Stokes, M. A., Davis, C. S., and Koch, G. G. 1995. Categorical Data Analysis Using SAS System. SAS Institute, Cary, NC.

28. Sumner, D. R., Doupnik, B., Jr., and Boosalis, M. G. 1981. Effects of reduced tillage and multiple cropping on plant diseases. Annu. Rev. Phytopathol. 19:167-187.

29. Sumner, D. R., Threadgill, E. D., Smittle, D A., Phatak, S. C., and Johnson, A. W. 1986 Conservation tillage and vegetable diseases. Plant Dis. 70:906-911.

30. Tachibana, H. 1983. Association of Phytophthora root rot of soybean with conservation tillage. (Abstr.) Phytopathology 73:844

31. Tsao, P. H. 1983. Factors affecting isolation and quantitation of Phytophthora from soil Pages 219-236 in: Phytophthora: Its Biology, Taxonomy, Ecology, and Pathology. D. C. Erwin, S. Bartincki-Garcia, and P. H. Tsao, eds. American Phytopathological Society, St. Paul, MN.

32. Weste, G. 1983. Population dynamics and survival of Phytophthora. Pages 237-257 in: Phytophthora: Its Biology, Taxonomy, Ecology, and Pathology. D. C. Erwin, S. BartinckiGarcia, and P. H. Tsao, eds. American Phytopathological Society, St. Paul, MN.

33. Workneh, F., van Bruggen, A. H. C., Drinkwater, L. E., and Shennan, C. 1993 Variables associated with corky root and Phytophthora root rot of tomatoes in organic and conventional farms. Phytopathology 83:581-589.

34. Wrather, J. A., Anderson, T. R., Arsyad, D. M., Gai, J., Ploper, L. D., Porta-Puglia, A., Ram, H. H., and Yorinori, J. T. 1997. Soybean disease loss estimates for the top 10 soybean producing countries in 1994. Plant Dis. 81:107-110.

35. Yang, X. B., Ruff, R. L., Meng, X. Q., and Workneh, F. 1996. Races of Phytophthora sojae in Iowa soybean fields. Plant Dis. 80:1418-1420. 